\title{
ОРГАНІЗАЦІЙНО-ПРАВОВІ ПИТАННЯ СТВОРЕННЯ КРЕДИТНИХ СПІЛОК В УКРАЇНI
}

\author{
БУГА Ганна Сергіївна - кандидат юридичних наук, доцент, доцент кафедри \\ адміністративно-правових дисциплін факультету № 2 Донецького державного \\ університету внутрішніх справ
}

УДК 347.732

DOI 10.32782/NP.2021.4.6

\begin{abstract}
У статті розглянуто організаційно-правові питання створення $і$ бункиіонування кредитних спілок в Україні. Констатовано, що такі небанківсъкі ббінансові установи займають найбільшу частку, здійснюючи свою діяльність на умовах самобінансування й неприбутковості, трансбормуючись у псевдокооперативні борми. Доведено, що професійна діяльність кредитних спілок на ринку бінансових послуг України має базуватися на єдиних кооперативних стандартах, які відповідають приниипам і критеріям кредитної кооперачій та ідентифбікують цей бінансовий інститут як класичну кооперативну бінансову установу.

Ключові слова: небанківська ббінансова установа, Фбінансова безпека, кредитна спілка, організачія, створення.
\end{abstract}

Ринки фінансових послуг - це важлива та невід'ємна складова економіки кожної держави. Як і будь-який сегмент економіки, вони потребують відповідної системи державного регулювання. Вибір оптимальної моделі такого регулювання є надзвичайно актуальним пріоритетом подальшого розвитку фінансової галузі. Водночас такий вибір неможливий без аналізу процесів виникнення та еволюції державного управління ринками фінансових послуг на території України. Адже проведення такого аналізу дасть змогу відібрати найкраще 3 досвіду минулого та запобігти повторенню помилок, які вже було колись зроблено в цій сфері.
Еволюційний шлях кредитної кооперації є надзвичайно складним і тривалим. У кожній державі вона мала специфічні ознаки та форми. Батьківщиною кооперативного руху вважають Західну Европу. Передумовою його виникнення був економічний та соціальний прогрес сільського господарства. У XIX столітті процес виникнення сільських кооперативів, ініціаторами створення яких були мешканці сільської місцевості, стимулював потребу в забезпеченні стабільних зв'язків дрібного та середнього селянства $з$ ринком сільськогосподарської продукції [1, с. 65].

Глобальні ринкові перетворення в Україні стимулювали появу самотніх, соціально незахищених громадян, які потребували захисту та допомоги у сфері надання фінансових послуг. На жаль, послуги, які пропонували різноманітні фінансові установи, були дорогими та складними в оформленні. Здебільшого цим особам відмовляли в задоволенні фінансових потреб. До того ж, різко знижувався рівень життя. Зазвичай за таких умов люди не аналізують, хто винен, а вважають, що їх не захистили профспілки. Тому одним із головних завдань стало зменшення негативного впливу процесів реформування на осіб шляхом поліпшення умов їхнього життя.

Кредитний рух в Україні виник у XIX столітті, під час провадження олександрійських реформ, коли завдяки скасуванню кріпосного права та реорганізації поміщицького землеволодіння селяни отри- 


\section{Адміністративне право}

мали власні земельні ділянки й можливість господарювати на них на власний розсуд. Надто низька фінансова спроможність колишніх кріпаків спонукала їх до кооперації $[2$, с. 53]

Одними 3 перших крайове кредитове товариство утворили поміщики Галичини 3 метою надання позик під заставу нерухомого майна. Подібним товариствам були притаманні окремі ознаки сучасних кредитних спілок. Зокрема, їх діяльність була спрямована не на отримання прибутку, а на задоволення суспільних потреб у кредитуванні.

Як засвідчують результати дослідження сучасних науковців, становлення кооперативного руху в Україні відбувалося на межі XIX-XX століть. Соціально-економічні умови Російської та Австро-Угорської імперій, що панували на українських землях, гальмували розвиток нового типу господарської організації мас, що була фактично окремою демократизованою формою економічного життя [3, с. 17; 4, с. 336].

Основоположниками українського кооперативного руху були Х. Барановський, С. Бородаєвський, К. Аевицький, Б. Мартос, К. Мацієвич, Ю. Павликовський, М. Туган-Барановський та ін.

У галицьких крайових закладах акціонерні засади змішувались із засадами взаємності [5, с. 103-104]. У 1866 році в Петербурзі вперше створено Товариство взаємного поземельного кредиту, яке поширило свою діяльність і на українські губернії. Особливістю цього Товариства було те, що його капітал формувався 3 внесків членів і кредит могла одержати лише особа, яка внесла свій пай. Aле оскільки такі товариства задовольняли потреби у кредиті лише великих землевласників, то в містах і селах почали створювати невеликі кредитні кооперативи.

Уперше позичково-ощадне товариство заснували міщани м. Гадяч на Полтавщині в 1869 році. Розвитку селянських ощаднопозичкових товариств перешкоджали дві основні проблеми: по-перше, більшість селян не мали засобів для внеску (паю); подруге, існувала потреба в тривалішому за строком кредиті, ніж спроможні були запропонувати ці товариства.
Тому першим українським кредитним кооперативам як органам фінансової взаємодопомоги складно було конкурувати з банками та лихварями, незважаючи на різницю відсотків. Розв'язало ці проблеми Положення про установи дрібного кредиту, прийняте царським урядом у 1895 році [6, с. 109].

Згідно з цим Положенням, позиковоощадні товариства набули права видавати довгострокові позики. До того ж, вони створювали організації дрібного кредиту. Членом такого крайового товариства можна було стати без вступного внеску. На формування позикового капіталу уряд Російської імперії виділив певні кошти.

Отже, праобрази сучасних кредитних спілок виникли на Україні ще в другій половині ХІХ століття. Їхня діяльність грунтувалася на засадах кооперації. Такі товариства загалом надавали короткострокові позики, але під незначні відсотки. Найпоширенішим видом забезпечення вважалась іпотека. Активність учасників кредитних відносин у пореволюційний період стала результатом зміни ідеології щодо питання власника землі [4, с. 337-338].

Наступна хвиля піднесення розвитку кредитних спілок припадає на початок XX століття - період Столипінської аграрної реформи, основна ідея якої полягала в ліквідації общинного землеволодіння і реалізації селянами економічної свободи господарювання [4, с. 337]. У «Всезагальному російському календарі» того часу описано феномен відродження сибірського села Стара Барда, де завдяки успішній діяльності кредитної спілки, заснованої односельчанами, вдалося побудувати молокопереробний завод, налагодити торгівлю, електрифікувати, телефонізувати всю околицю, а з часом - заснувати дослідницьку тваринну ферму, організувати посіви кормових буряків і трав [3, с. 23].

3 урахуванням особливостей розвитку кредитних спілок цілком логічним виявляється третій етап їх бурхливого розвитку в період непу вже за радянських часів (19211924 роки), коли було дозволено відновлювати спілки. Після огульної націоналізації землі селянам дозволяли вести присадибне 
господарство. Політика продрозверсток, інфляція (у 1917 році становила $75 \%$, а у 1918 році - $200 \%$ ), а також тотальне зубожіння населення стимулювало прагнення більшовиків відродити національну економіку та зняти соціальну напругу за допомогою такого інструменту, як кредитна спілка [2, с. 53-54].

Після проголошення незалежності України почався процес відродження кредитних спілок як організацій реальної взаємної допомоги між громадянами в разі виникнення тимчасових фінансових труднощів. Зазначені установи відіграли важливу роль у розвитку роздрібного та малого бізнесу в Україні, активно конкуруючи 3 банками на ринку фінансових послуг. Сучасний стан цих організацій потребує нових моделей розвитку та змін у регулюванні їньої діяльності. Нинішне суспільство як осередок потенційних клієнтів недостатньо поінформоване про діяльність кредитних спілок, оскільки поширення даних має здебільшого регіональний характер. Відсутність системної діяльності кредитних спілок на внутрішньому ринку та монополізація ринку фінансових послуг комерційними банками призводить до зниження рівня довіри населення до них як до надійних фінансових інституцій [7, с. 40].

Законом України «Про об'єднання громадян» від 16 червня 1992 року [8] закріплено норми, що стали на той час правовими засадами становлення кредитних спілок в Україні.

Визнанням факту існування таких організацій стало затвердження 20 вересня 1993 року Указом Президента України Тимчасового положення про кредитні спілки в Україні. Право на об'єднання фізичних осіб у громадські організації для задоволення економічних і соціальних інтересів закріплене в ст. 36 Конституції України [9].

Відсутність в Україні цивілізованого кооперативного законодавства призвела до того, що під час відродження кредитно-кооперативного руху організаційною формою кредитної спілки було обрано не кооператив, як це прийнято в усьому світі, а громадську організацію. 3 огляду на те, що діяльність громадських організацій недостатньо врегульована, а господарське законодавство спрямоване на регулювання підприємницької діяльності, у кредитних спілок виникало чимало труднощів у відносинах із державними органами [10, с. 114].

Розвиток фінансового сектору, підприємництва та конкурентного середовища в Україні призводять до перебудови всіх складових фінансового ринку, зокрема ринку фінансових послуг. Причому нового значення набуває діяльність фінансових посередників, передусім небанківських фінансових інститутів, які задовольняють потреби економічних суб'єктів через надання широкого спектру вузькоспеціалізованих фінансових послуг. Це зумовлюе зростання конкурентного потенціалу окремих небанківських фінансових посередників, що охоплюють максимальну кількість споживачів на різних рівнях економічної діяльності $[11$, c. 273].

Особливість сучасного етапу розвитку небанківських фінансових інститутів полягає в необхідності поліпшення не лише кількісних, а й якісних показників їх діяльності на ринку фінансових послуг. Перебудова та підвищення ефективності системи функціонування небанківських фінансових посередників стає найважливішим фактором, що здатний забезпечити розвиток ринку фінансових послуг України [12, с. 11].

Відповідно до ст. 1 Закону України «Про фінансові послуги та державне регулювання ринків фінансових послуг» небанківська фінансова група - група юридичних осіб, які мають спільного контролера (крім банку), що складається 3 двох або більше фінансових установ, у якій небанківська фінансова установа (небанківські фінансові установи) здійснює переважну діяльність [13].

Нині неабиякої значущості набувають фінансові установи, діяльність яких спрямована на соціальний розвиток, зокрема на захист населення від знецінення коштів, надання громадянам фінансових послуг. Такі ознаки притаманні так званим кредитним коопераціям, які в Україні діють як кредитні спілки. Для того щоб встановити порядок створення кредитної 


\section{Адміністративне право}

спілки, під якою відповідно до ст. 1 Закону України «Про кредитні спілки» розуміють неприбуткову організацію, неприбуткова організація, заснована фізичними особами, професійними спілками, їх об'єднаннями на кооперативних засадах з метою задоволення потреб її членів у взаємному кредитуванні та наданні фінансових послуг за рахунок об'єднаних грошових внесків членів кредитної спілки [14], необхідно з'ясувати iї мету та принципи організації.

Згідно із законодавством, основними принципами діяльності кредитних спілок є: добровільність вступу та свободи виходу 3 кредитної спілки, рівноправність ії членів, самоврядування, гласність, законність [14]. На нашу думку, добровільність вступу до кредитної спілки є принципом створення, а не діяльності кредитної спілки, який полягає у тому, що ніхто не може бути примушений вступити до кредитної спілки.

На думку науковців, кредитні спілки створюються і діють на певних засадах. Так, Р. Слав'юк зазначає, що кредитна спілка створюється на базі певного існуючого територіального чи професійного об'єднання, громадської чи релігійної організації, територіальної одиниці, трудового колективу і іншого формального чи неформального об'єднання, у якому люди знають один одного [15, с. 97].

Такі виділені засади, на яких особи об’єднуються для вступу в кредитну спілку, надає можливість поділити кредитні спілки на такі види:

1. об'єднання осіб, які проживають на певній території (село, селище, місто, район, область).

2. об’єднання осіб, які мають спільне місце роботи чи навчання.

3. об'єднання осіб, які належать до однієї місцевої профспілкової, іншої громадської чи релігійної організації.

Такі види обумовлені законодавчими принципами створення кредитних спілок в Україні. Разом з тим, Р. Ковтун вважає, що існує декілька моделей кредитних спілок, зокрема:

- на базі підприємств. Іншими словами, у кредитну спілку входять працівники одного підприємства. Цей вид кредитної спілки, на думку автора, є найоптимальнішим. У цьому випадку ризик неповернення позики мінімальний, оскільки члени кредитної спілки знають один одного, знають фінансові можливості один одного. Більшість позик видаються на придбання товарів, на навчання, лікування. Процентні ставки на позики в таких кредитних спілках, як правило, невеликі за рахунок того, що проценти на вклади в кредитній спілці теж невеликі. До того, ж кредитна спілка, як правило, підписує угоди 3 підприємствами торгівлі і отримує дисконт. Це дає можливість ще більше знизити кредитну ставку;

- у сільському районі. Такий вид кредитних спілок найбільш розповсюджений на Західній Україні. Такі кредити видаються на строк від трьох місяців до одного року. Фермери одержують позику під майбутній урожай, заставляючи свою техніку. Досить часто кредит видається на покупку сільськогосподарської техніки [16, с. 17].

В. В. Гончаренко виділяє чотири типи кредитних спілок, які на сьогодні діють в Україні: профспілковий, ломбардний, інвестиційний та ощадно-позичковий.

Профспілковий тип кредитної спілки часто створюється на базі та за принципом колишніх кас взаємодопомоги, які раніше існували на підприємствах, в установах та організаціях. Як правило, такі кредитні спілки об'єднують членів трудового колективу підприємства, користуються наданими профспілковим комітетом та (чи) адміністрацією приміщеннями і коштами. Вони мають обмежений набір ощадних послуг: приймають щомісячні обов'язкові членські внески, проценти на які нараховуються за фактом роботи в кінці року та, як правило, мають незначний розмір. Стимулювання накопичення членами власних заощаджень у вигляді строкових, ощадних, цільових та інших вкладів, як правило, не передбачається. Такі спілки видають переважно споживчі кредити порівняно невеликих розмірів під довіру чи поручительство членів або підприємства.

Зазвичай заощадження членів не є єдиним джерелом формування коштів позичкового фонду, значною $є$ частка коштів, 
отриманих від підприємства чи профспілки. Інколи керівники підприємства та члени профспілкового комітету становлять більшість в органах управління спілкою такого типу, а сама спілка використовується для можливих фінансових операцій з коштами підприємства чи профспілки. За механізмом цієї діяльності цей тип кредитної спілки найбільше нагадує касу взаємодопомоги.

Ломбардний тип кредитної спілки найчастіше створюється за територіальним принципом, так би мовити, «на вулиці». Кредитна спілка такого типу, як правило, має кілька великих членів-вкладників, які контролюють iï чи доручають свої гроші своїй довіреній особі. Кредити видаються під заставу будь-якій особі, яка формально приймається у члени спілки, а після повернення кредиту вибуває зі спілки «за власним бажанням.»

Кредитні спілки цього типу мають значні активи при незначній кількості постійних членів, які виходять зі спілки після повернення кредиту. У таких спілках велика частка (до 30) неповернутих кредитів і реалізованих унаслідок цього предметів застави. Фінансова політика спрямована на надання кредитів під порівняно великі проценти. Демократія у таких спілках часто обмежена. Демократичне вирішення питання існує тільки серед членів-вкладників. Позичальники, як правило, є тимчасовими членами, вони обмежені у реальних правах. За механізмом своєї діяльності цей тип кредитної спілки найбільше нагадує ломбард, а із західних аналогів - ощаднопозичкову асоціацію акціонерного типу.

Інвестиційний тип кредитної спілки часто створюється при якійсь комерційній структурі холдінгового або трастового типу i діє за територіальним принципом. Така кредитна спілка акумулює кошти дрібних вкладників під певні проєкти (будівництво житла, додаткове пенсійне забезпечення, постачання товарів та ін.), має багато видів ощадних або цільових внесків. Спілки цього типу мають значну суму активів та багато членів, котрі, як правило, мають дрібні вклади і малоактивні. Фінансова політика у них спрямована на залучення дрібних ко- штів, їх концентрацію та інвестування у великих розмірах. Форма кредитної спілки, особливо такого типу, потенційно може бути використана для побудови фінансової піраміди. У таких спілках через велику кількість членів, майже не проводяться щорічні загальні збори. До складу органів правління переважно входять засновники, яких не переобирають загальними зборами. За механізмом своєї діяльності спілки такого типу нагадують із західних аналогів інвестиційну чи трастову компанії.

Ощадно-позичковий тип кредитної спілки найнаближеніший до кредитних спілок західного зразка. Це демократична організація, у якій немає чітко вираженої вузької групи людей (вкладників чи позичальників), в інтересах якої діє спілка. Фінансова політика, спрямована на надання дешевих кредитів, та нарахування вищих, ніж в інших фінансових установах, процентів на вклади членів спілки. $\mathbb{E}$ різноманітні умови вкладів і позичок. При можливості надаються інші види послуг, не заборонених чинним законодавством. Усі члени спілки рівноправні. Правління, кредитний та наглядовий комітети обираються щорічно загальними зборами і виконують покладені на них функції. Зростання кількості членів та активів, як правило, здійснюється поступово [17, с. 85-88].

Розглянувши організаційно-правові питання створення і функціонування кредитних спілок, можна зробити висновки:

по-перше, на відміну від інших фінансових установ, які, як правило, створюються однією групою людей (власниками) для отримання прибутку від надання фінансових послуг іншій групі людей (клієнтам), кредитна спілка створюється групою людей для забезпечення фінансовими послугами на основі кооперації. Метою діяльності кредитної спілки $є$ не отримання прибутку, а надання різноманітних нансових послуг виключно своїм членам. Члени спілки є одночасно ï̈ власниками і клієнтами, тому кредитній спілці вдається поєднати інтереси власників (максимізація прибутку) та клієнтів (мінімізація витрат). Прибуток, отриманий від членів як від клієнтів, розподіляється між ними як між 


\section{Адміністративне право}

власниками за загальним рішенням. Законодавство більшості країн світу відносить кредитні спілки до неприбуткових організацій;

по-друге, кредитні спілки створюються на базі певного існуючого територіального чи професійного об'єднання, громадської чи релігійної організації, територіальної одиниці, трудового колективу, іншого формального чи неформального об'єднання, у якому люди, як правило, знають одне одного. Інші фінансові установи створюються на базі штучно сформованої групи;

по-третє, на відміну від інших фінансових установ, при заснуванні кредитної спілки не визначається фіксована чи потенційна кількість людей, які будуть їі власниками. Передбачається, що спілка буде зростати і кількість власників постійно збільшуватиметься;

по-четверте, статут і всі принципові рішення щодо діяльності кредитних спілок приймаються загальними зборами, на яких кожен член спілки має один голос, незалежно від суми внесків і часу вступу до спілки. Особи, які створили спілку, не мають жодних привілеїв чи виняткових прав порівняно $з$ іншими членами, які вступили до спілки пізніше. В інших фінансових установах розподіл голосів здійснюється відповідно до частки в майні (кількості акцій);

по-п'яте, кредитна спілка $є$ водночас формою взаємодопомоги громадян, їхньою громадською організацією, яка створює різноманітні колективні фонди, що використовуються на суспільні потреби, та фінансовою установою, яка може надавати своїм членам повний перелік банківських послуг;

по-шосте, кредитна спілка створюється на кооперативних засадах відповідно до принципів: добровільності, рівноправності, самоврядування і гласності. Ї̈̈ метою 6 задоволення потреб ії членів у взаємному кредитуванні та наданні їм фінансових послуг;

по-сьоме, кошти кредитної спілки формуються за рахунок грошових внесків членів кредитної спілки. Оскільки кредитна спілка може бути членом об'єднаної кре- дитної спілки, вона може залучати для кредитування також кошти останньої. Тому викликає сумнів доцільність включення у законодавче визначення кредитної спілки положення, що фінансові послуги кредитна спілка здійснюе за рахунок об'єднаних грошових внесків членів кредитної спілки.

Підводячи підсумки, варто зазначити, що кредитна спілка є неприбутковою організацією, створеною групою фізичних осіб для забезпечення останніх фінансовими послугами на основі кооперації. Метою діяльності кредитної спілки є надання різноманітних фінансових послуг лише своїм членам. Члени спілки є одночасно ії власниками і клієнтами, тому кредитна спілка поєднує інтереси власників (максимізація прибутку) та клієнтів (мінімізація витрат). Капітал формується за рахунок грошових внесків своїх членів. Оскільки кредитна спілка може бути членом об'єднаної кредитної спілки, вона може залучати для кредитування також кошти останньої. Тому пропонуємо внести зміни до Закону України «Про кредитні спілки», виклавши ч. 1 ст. 1 у такій редакції: «Кредитна спілка - це заснована фізичними особами на кооперативних засадах та принципах добровільності, рівноправності, самоврядування і гласності неприбуткова організація, метою якої є задоволення потреб їі членів у взаємному кредитуванні та наданні фінансових послуг за рахунок об'єднаних грошових внесків».

\section{Лiтература}

1. Дадашев Б. А., Гриценко О. I. Кредитні спілки України : навч. посіб. Київ, 2010. 112 с.

2. Духневич А. В. Кредитні спілки в Україні: історія та сучасність : навч. посіб. Ауцьк, 2010. 234 с.

3. Історія кооперативного руху : підручник / С. Г. Бабенко, С. Д. Гелей, Я. А. Гончарук та ін. Аьвів, 1995. 410 с.

4. ภепех С. Кредитні спілки в україні: історія і сучасність. Вісник Аьвісъкого університету. № 36. 2001. С. 336-339.

5. Цяпало О. С. Іпотечні банки Галичини наприкінці XIX на початку 
ХХ ст. Фінанси Украйни. 2005. № 5. С. 103108.

6. Кульчицька Р. Б., Щибиволок 3. І. 3 історії ощадної справи східної України. Фінанси Украӥни. 2007. № 1. С. 108-112.

7. Єлісєева О., Стоянов Г. Сучасний стан розвитку кредитних спілок україни. Фінансовий сектор. 2013. № 4. С. 40-43.

8. Про об’єднання громадян : Закон України від 16 черв. 1992 р. № 2460XII. URL: http://zakon3.rada.gov.ua/laws/ show/2460-12.

9. Конституція України : Закон України від 28 черв. 1996 р. № 254к/96BP. URL: http://zakon2.rada.gov.ua/laws/ show $/ 254 \% \mathrm{D} 0 \% \mathrm{BA} / 96-\% \mathrm{D} 0 \% \mathrm{~B} 2 \% \mathrm{D} 1 \% 80$.

10. Тахтай О. В. Кредитні спілки: історія виникнення та сучасний розвиток. $\mathrm{Ha}$ уковий вісник Начіональної академї внутрішніх справ. 2016. № 4 (101). С. 110-119.

11. Тахтай О. В. Становлення та розвиток механізму державного регулювання діяльності небанківських фінансових установ в Україні. Юридичний часопис Нащіональної академії внутрішніх справ. 2016. № 2 (12). C. 273-282.

12. Каракулова I. С. Небанківські фінансові інститути на ринку фінансових послуг України : дис. ... канд. екон. наук : 08.00.08. Київ, 2008. 219 с.

13. Про фінансові послуги та державне регулювання ринків фінансових послуг : Закон України від 12 лип. 2001 р. № 2664III. URL: http://zakon3.rada.gov.ua/laws/ show/2664-14.

14. Про кредитні спілки : Закон від 20 груд. 2001 р. № 2908-III. Верховна Рада україни. URL: http://zakon2.rada.gov.ua/ laws/show/2908-14.

15. Слав'юк Р. А. Кооперативні кредитні установи у фінансовому забезпеченні розвитку аграрного бізнесу. Фінанси України. 2000. № 2. С. 96-103.

16. Ковтун Р. Шило на мыло. Бизнес. 1999. № 38. C. 17.

17. Гончаренко В. В. Особливості відродження кредитної кооперації. Фінанси Украӥни. 1999. № 12. С. 82-90.

\section{ORGANIZATIONAL AND LEGAL ISSUES OF GREATION CREDIT UNIONS IN UKRAINE}

The article considers organizational and legal issues of creation and functioning of credit unions in Ukraine. It is stated that such non-bank financial institutions occupy the largest share, carrying out their activities on the terms of self-financing and nonprofitability, transforming into pseudo-cooperative forms. The professional activity of credit unions in the financial services market of Ukraine should be based on uniform cooperative standards that meet the principles and criteria of credit cooperation and identify this financial institution as a classic cooperative financial institution.

There are four types of credit unions that currently operate in Ukraine: trade union, pawnshop, investment and savings and loan. Having considered the organizational and legal issues of the establishment and operation of credit unions, the conclusions are made: unlike other financial institutions, which are usually created by one group of people (owners) to profit from financial services to another group of people (customers), a credit union a group of people to provide financial services on a cooperative basis. The purpose of the credit union is not to make a profit, but to provide a variety of financial services exclusively to its members. The members of the union are both its owners and customers, so the credit union manages to combine the interests of owners (profit maximization) and customers (cost minimization). Profits received from members as customers are distributed among them as owners by common decision. The legislation of most countries of the world classifies credit unions as non-profit organizations; Unlike other financial institutions, the establishment of a credit union does not determine the fixed or potential number of people who will own it. It is expected that the union will grow and the number of owners will constantly increase; the charter and all principal decisions on the activities of credit unions are made by the general meeting, at which each member of the union has one vote, regardless of the amount of contributions and the time of joining the union. The 


\section{Адміністративне право}

y статті розглянуто організачійно-правові питання створення $i$ бункціонування кредитних спілок в Україні. Констатовано, що такі небанківські бінансові установи займають найбільшу частку, здійснюючи свою діяльність на умовах самофінансування й неприбутковості, трансбормуючись у псевдокооперативні форми. Професійна діяльність кредитних спілок на ринку фінансових послуг Украӥни має базуватися на єдиних кооперативних стандартах, які відповідають принизиам $i$ критеріям кредитної коопераиіӥ та ідентифікують изей фінансовий інститут як класичну кооперативну бінансову установу.

Виділено чотири типи кредитних спілок, які на съогодні діють в Україні: пробспілковий, ломбардний, інвестииійний та ощадно-позичковий. Розглянувши організаиійно-правові питання створення і бункиіонування кредитних спілок, зроблені висновки: на відміну від інших бінансових установ, які, як правило, створюються однією групою людей (власниками) для отримання прибутку від надання фінансових послуг іншій групі людей (клієнтам), кредитна спілка створюється групою людей для забезпечення фінансовими послугами на основі коопераціӥ. Метою діяльності кредитної спілки є не отримання прибутку, а надання різноманітних фінансових послуг лише своїм членам. Члени спілки є одночасно ї̈ власниками i клієнтами, тому кредитній спілиі вдається поєднати інтереси власників (максимізація прибутку) та клієнтів (мінімізація витрат). Прибуток, отриманий від членів як від клієнтів, розподіляється між ними як між власниками за загальним рішенням. Законодавство більшості країн світу відносить кредитні спілки до неприбуткових організачій; на відміну від інших ббінансових установ, при заснуванні кредитної спілки не визначається боксована чи потениійна кількість людей, які будуть ï власниками. Передбачається, що спілка буде зростати $i$ кількість власників постійно збільиуватиметься; статут $i$ всі принициові рішення щодо діяльності кредитних спілок приймається загальними зборами, на яких кожен илен спілки має один голос, незалежно від суми внесків і иасу вступу до спілки. Особи, які створили спілку, не мають жодних привілеїв чи виняткових прав порівняно з іншими членами, які вступили до спілки пізніше. В інших фбінансових установах розподіл голосів здійснюється відповідно до частки в майні (кількості акцій); кредитна спілка $е$ водночас бормоюо взаємодопомоги громадян, їхнъою громадсъкою організачією, яка створюе різноманітні колективні бонди, що використовуються на суспільні потреби, та фінансовою установою, яка може надавати своїм иленам повний перелік банківсъких послуг; кошти кредитної спілки бормуються за рахунок грошових внесків иленів кредитної спілки. Оскільки кредитна спілка може бути членом об'єднаної кредитної спілки, вона може залучати для кредитування також кошти останнъої. Тому викликає сумнів доцільність включення у законодавче визначення кредитної спілки положення, шоо фінансові послуги кредитна спілка здійснює за рахунок об'єднаних грошових внесків иленів кредитної спілки.

Ключові слова: небанківсъка фінансова установа, бінансова безпека, кредитна спілка, організація, створення.

people who formed the union do not have any privileges or exclusive rights compared to other members who joined the union later. In other financial institutions, the distribution of votes is carried out according to the share in the property (number of shares); a credit union is at the same time a form of mutual assistance of citizens, their public organization, which creates various collective funds used for public needs, and a financial institution that can provide its members with a full range of banking services; the funds of the credit union are formed at the expense of monetary contributions of the members of the credit union. Because a credit union may be a member of a consolidated credit union, it may also raise funds from the latter. Therefore, the expediency of including in the legislative definition of a credit union the provision that the credit union provides financial services at the expense of the combined monetary contributions of the members of the credit union is questionable.

Keywords: non-bank financial institution, financial security, credit union, organization, creation. 